\title{
EFFECTS OF FUSARIUM SPECIES ON DEFENCE MECHANISMS IN SORGHUM SEEDLINGS
}

\author{
L-D. HUANG and D. BACKHOUSE
}

\begin{abstract}
Botany, School of Environmental Sciences and Natural Resources Management, University of New England, Armidale, NSW 2351, Australia

Corresponding author:lhuang@pobox.une.edu.au
\end{abstract}

\begin{abstract}
Sorghum seedlings were inoculated with Fusarium proliferatum and $F$. thapsinum 3 days after germination. Seven days later, infected seedlings were dissected into the coleoptile, mesocotyl, seed, scutellum and root, and defence responses measured. Infection significantly increased the levels of soluble phenolics and anthocyanins, the phytoalexins apigeninidin and luteolinidin, and the enzymes peroxidase, $\beta$-1,3-glucanase and chitinase in some tissues. Constitutive levels of chitinase were high. The strongest defence responses, and highest levels of pre-formed defences, were seen in the scutellum. Responses to $F$. thapsinum tended to be stronger than those to $F$. proliferatum. The findings supported the hypothesis that the plant is able to suppress the activity of these fungi during the endophytic stage of infection.
\end{abstract}

Keywords: Fusarium, sorghum, resistance, phytoalexin, pathogenesisrelated proteins.

\section{INTRODUCTION}

Sorghum (Sorghum bicolor) is one of the major cereal crops, especially in hot and dry areas of the world. Species of Fusarium cause several diseases of sorghum, including root rots, seedling blights, stalk rot and grain mould. They can also produce mycotoxins that are toxic to humans and animals. Some species such as $F$. thapsinum and F. proliferatum can colonise sorghum symptomlessly as endophytes (Leslie 2000), as well as turning pathogenic when plants are stressed.

Most research on defence mechanisms of sorghum has focused on developing caryopses, with a view to finding ways to reduce grain mould (Little 2000). A broad suite of pre-formed and induced responses has been identified in sorghum grains, especially accumulation of products of phenylpropanoid metabolism and pathogenesisrelated proteins such as chitinases and $\beta$-1,3-glucanases. Much less is known about defence responses in vegetative tissues or seedlings. Nicholson et al. (1987) identified the deoxyanthocyanin phytoalexins apigeninidin and luteolinidin in mesocotyls of seedlings inoculated with necrotrophic leaf-spotting fungi. However, it is not known whether plants would respond in the same way to endophytic infection, or whether defence mechanisms are similar in all tissues in seedlings.

This paper reports the effects of two Fusarium species on defence responses in different parts of sorghum seedlings. The responses examined include examples of general phenylpropanoid metabolism, phytoalexins, and pathogenesis-related proteins.

\section{METHODS}

Sorghum seeds (cv. Jumbo) were surface-sterilised and treated with hot water to remove internal fungi. Seeds were germinated in $300 \mathrm{ml}$ glass jars containing $20 \mathrm{ml}$ of $8 \mathrm{~g} /$ litre carrageenan gel (Gelcarin GP812, Swift and Co., Rosehill, Australia) and incubated at $25^{\circ} \mathrm{C}$ in the dark. After 3 days seedlings were inoculated by placing $200 \mu \mathrm{l}$ of a microconidial suspension of either $F$. thapsinum (isolated from sorghum) or $F$. proliferatum (isolated from Johnson grass, S. halapense) at $5 \times 10^{7}$ spores $/ \mathrm{ml}$ on the 
surface of the gel. Uninoculated seedlings were used as controls. After a further 7 days plants were harvested and dissected into five parts: coleoptile, mesocotyl, seed (effectively the seed coat and endosperm), scutellum and root. There were three replicates for each assay.

Soluble phenolics and anthocyanins were extracted with $95 \%$ EtOH containing $0.1 \% \mathrm{HCl}$. Anthocyanins were measured spectrophotometrically at $490 \mathrm{~nm}$. Phenolics were measured using the Folin-Ciocalteu reagent method with spectrophotometric assay at $750 \mathrm{~nm}$ (Andarwulan \& Shetty 1999).

Detection of apigeninidin and luteolinidin with high performance liquid chromatography (HPLC) was based on Nicholson et al. (1987). Filtered acidic ethanol extracts were separated with two reverse-phase $\mathrm{C}_{18}$ columns connected in tandem using a linear gradient from 0 to $100 \%$ solvent $\mathrm{B}$ (methanol:acetic acid $=9: 1, \mathrm{vol} / \mathrm{vol}$ ) over 33 min followed by $100 \%$ solvent B for 5 min, after which the column was cleaned with a linear gradient back to $100 \%$ A (water:acetic acid:methanol $=71: 10: 9$, vol $/ \mathrm{vol}$ ) in $1 \mathrm{~min}$ and allowed to re-equilibrate at $100 \%$ A for $15 \mathrm{~min}$. The flow rate was $1 \mathrm{ml} / \mathrm{min}$ and detection was at $480 \mathrm{~nm}$. Sample $(20 \mu \mathrm{l})$ was injected into the chromatograph. Standards of luteolinidin and apigeninidin were obtained from Extrasynthese, Genay, France.

Enzyme extraction and colorimetric assays for $\beta$-1,3-glucanase, chitinase and peroxidase were done according to Dann \& Deverall (2000).

Data were analysed using ANOVA and Fisher's protected least significant difference.

\section{RESULTS}

Both Fusarium species stimulated sorghum seedlings to accumulate more soluble phenolics than the control in all five organs (Fig.1a). The strongest reaction to infection was in the scutellum, which also had the highest soluble phenolic content in the uninfected seedlings. The defence response to $F$. thapsinum was significantly greater $(\mathrm{P}<0.05)$ than to $F$. proliferatum in the seed, although the magnitude of this difference was small.

The pattern of accumulation of total anthocyanins was similar to that of total phenolics, although the levels in control seedlings were very low and the effect of $F$. thapsinum did not differ from that of $F$. proliferatum (data not shown).

Both Fusarium species induced sorghum seedlings to accumulate more apigeninidin than the control in the coleoptile, mesocotyl, scutellum and root (Fig. 1b). Fusarium proliferatum also caused a significant increase $(\mathrm{P}<0.05)$ in apigeninidin in the seeds. The pattern of accumulation of luteolinidin was similar to that of apigeninidin, except that neither species increased luteolinidin content of the seeds (data not shown).

The level of $\beta$-1,3-glucanase activity in the scutellum was significantly increased $(\mathrm{P}<0.05)$ by infection with both fungi and $F$. thapsinum had a significantly greater $(\mathrm{P}<0.05)$ effect than $F$. proliferatum. Fusarium thapsinum also significantly $(\mathrm{P}<0.05)$ increased $\beta$-1,3-glucanase activity in the roots (Fig. 1c). The scutellum showed the greatest activity of $\beta$-1,3-glucanase. The patterns of constitutive and induced peroxidase activity (data not shown) were similar to those of $\beta$-1,3-glucanase activity except that the effects of the two fungal species did not differ significantly.

In contrast to the other enzymes, infection with Fusarium fungi only had significant $(\mathrm{P}<0.05)$ effects on chitinase activity in the coleoptiles and roots (Fig. 1d). Constitutive levels of chitinase activity were high relative to induced activity in all tissues.

\section{DISCUSSION}

Infection with both $F$. thapsinum and $F$. proliferatum induced a broad range of defence responses in sorghum seedlings. These included soluble phenolics and anthocyanins, the phytoalexins apigeninidin and luteolinidin, and the pathogenesis related proteins, peroxidase, chitinase and $\beta$-1,3-glucanase. These responses are similar to those induced by necrotrophic pathogens (Nicholson et al. 1987; Little 2000). This indicates that the endophytic stage of infection by these fungi does not involve an avoidance of recognition. Rather, it fits the model of Schulz et al. (1999) which says that the activity of endophytes 
is suppressed by the defence mechanisms of the plant. Pathogenesis would then result from a breakdown in this suppression. This suggests that it would be worthwhile examining the processes involved in the onset of pathogenicity with a view to increasing the resistance of the plant.

(a)

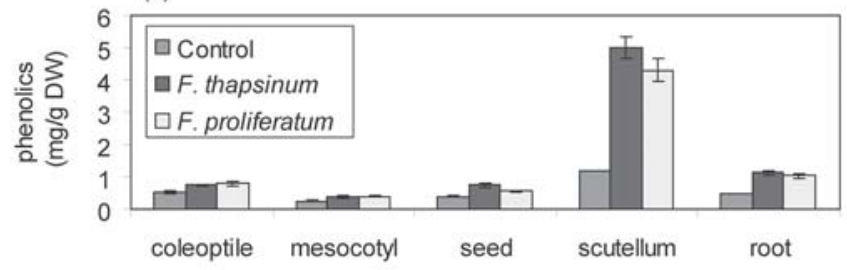

(b)

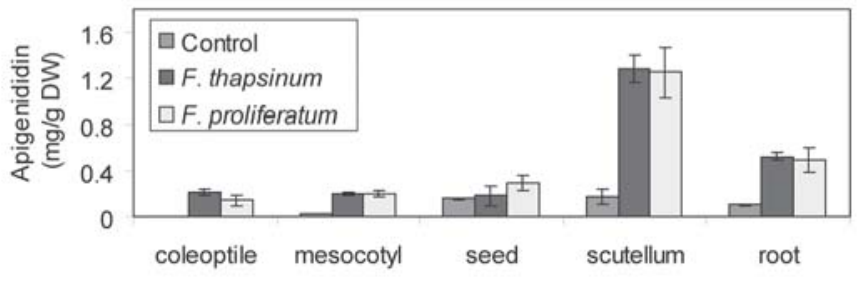

(c)

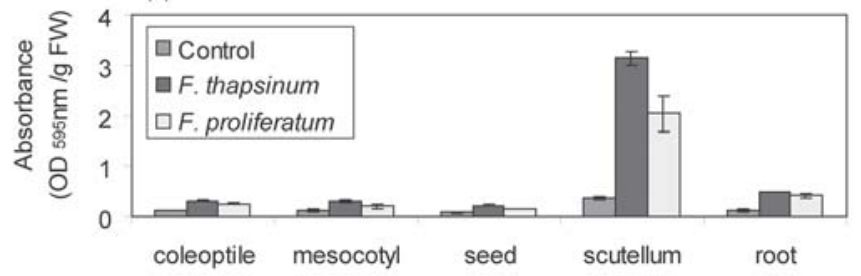

(d)

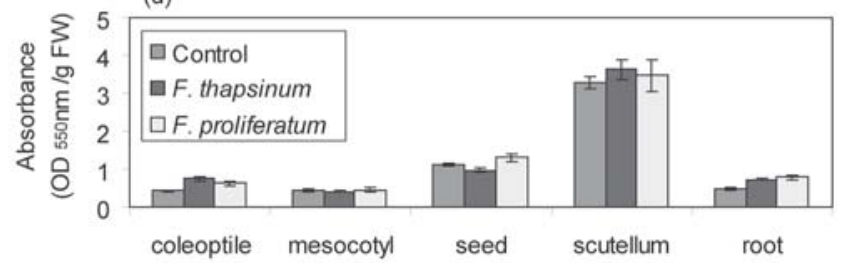

FIGURE 1: Levels of (a) soluble phenolics, (b) apigeninidin, (c) $\beta$-1,3-glucanase activity and (d) chitinase activity in five parts of sorghum seedlings 7 days after inoculation with $F$ usarium thapsinum and $F$. proliferatum. Error bars are \pm S.E $(n=3)$. 
Responses to $F$. thapsinum were greater than to $F$. proliferatum for phenolics and $\beta$-1,3-glucanase, at least in some tissues. Fusarium thapsinum is considered a more aggressive pathogen on sorghum than is $F$. proliferatum. The greater response to this species could be a reaction to its more aggressive nature. The weaker pathogenicity of $F$. proliferatum is not due to a higher level of defence reaction by the plant.

Both constitutive and induced responses were greatest in the scutellum. Microscopical observations (data not shown) indicated that the fungi entered the plant through the opening in the seed coat around the radicle. Therefore the scutellum was one of the first tissues challenged with infection. The scutellum has a major role to play in early growth of seedlings by transferring nutrients from the endosperm into the growing shoot and root. This tissue is therefore the one in greatest need of protection from infection. The high constitutive levels of defence compounds and pathogenesis-related proteins in the scutellum are consistent with reports of high levels of defence compounds in dormant seeds (Little 2000).

\section{REFERENCES}

Andarwulan, N.; Shetty, K. 1999: Phenolic content in differentiated tissue cultures of untransformed and Agrobacterium-transformed roots of anise (Pimpinella anisum L.). J. Agric. Food Chem. 47: 1776-1780.

Dann, E.K.; Deverall, B.J. 2000: Activation of systemic disease resistance in pea by an avirulent bacterium or benzothiadiazole, but not by a fungal leaf spot pathogen. Plant Path. 49: 324-332.

Leslie, J.F. 2000: Fusarium species associated with sorghum. In: Fredericksen, R.A.; Odvody, G.N. ed. Compendium of sorghum diseases, 2nd edition. APS Press, St Paul, USA. Pp. 30-31.

Little, C.R. 2000: Plant responses to early infection events in sorghum grain mould interactions. In: Chandrashekar, A.; Bandyopadhyay, R.; Hall, A.J. ed. Technical and institutional options for sorghum grain mould management. ICRISAT, Patancheru, India. Pp. 169-182.

Nicholson, R.L.; Kollipara, S.S.; Vincent, J.R.; Lyons, P.C.; Cadena-Gomez, G. 1987: Phytoalexin synthesis in the sorghum mesocotyl in response to infection by pathogenic and non-pathogenic fungi. Proc. Natl Acad. Sci. U.S.A. 84: 5520-5524.

Schulz, B.; Rommert, A.-K.; Dammann, U.; Aust, H.-J.; Strack, D. 1999: The endophytehost interaction: a balanced antagonism? Mycol. Res. 103: 1275-1283. 